\title{
TERNARY RHENIUM (I) COMPLEXES: FROM FLUORESCENT REPORTERS TO INTERESTING SCAFFOLDS FOR DUAL-IMAGING HETEROBIMETALLIC PROBES
}

\author{
Louise Marty*/**, Alison François*/**, Tetiana Krachko*/***, Chantal Galaup*/**, \\ Claude Picard $^{* / * *}$, V.M.Amirkhanov***, Eric Benoist*/**
}

* Université de Toulouse, UPS, Laboratoire de Synthèse et Physico-Chimie de Molécules d'Intérêt Biologique
** CNRS; Laboratoire de Synthèse et Physico-Chimie de Molécules d'Intérêt Biologique
*** Department of Chemistry, Taras Shevchenko National University of Kyiv, 64, str. Volodymyrska, Kyiv, 01601, Ukraine. E-mail: benoist@chimie.ups-tlse.fr; v_amirkhanov@yahoo.com

Key words: Click chemistry; ternary complexes; tricarbonylrhenium(I); fluorescence

In this paper, five new ternary tricarbonylrhenium(I) complexes based on a pyridinetriazole moiety, the so-called pyta, have been investigated. These cationic complexes of the general formula $\left[\operatorname{Re}(\mathrm{CO})_{3}(\right.$ pyta-COOMe $\left.) L\right](L=$ substituted pyridine derivatives) combine a carboxylate functionalization, for further biomolecule conjugation, with a metal chelating site - a pyta-based tricarbonylrhenium moiety - which can act as a fluorescent reporter. The complexes have been prepared using a two-steps pathway involved the activation of $\left[\operatorname{Re}(\mathrm{CO}){ }_{3} \mathrm{Cl}(\right.$ bipy)] with triflate silver salts in the presence of acetonitrile followed by the thermally activated substitution of the acetonitrile adduct by commercially available substituted pyridine derivatives. They have been prepared from modest to good yields, fully characterized by means of NMR, IR and mass spectrometry, and their photophysical properties have been investigated. Upon excitation into the MLCT band of each complex (absorption band at ca. $300 \mathrm{~nm}$ ), three of them exhibit a bright green luminescence centered at c.a. $494 \mathrm{~nm}$, with a quantum yield of $0.60 \%$ in acetonitrile. These interesting photophysical features make them potential fluorescent cellular imaging agents. Moreover, thank to their ancillary ligand, they could be also considered as interesting scaffolds for the preparation of dual-imaging heterobimetallic species.

РІЗНОЛІГАНДНІ КОМПЛЕКСИ РЕНІЮ(І): ВІД ФЛУОРЕСЦЕНТНИХ МІТОК ДО ГЕТЕРОБІМЕТАЛІЧНИХ ЗОНДІВ 3 ЦІКАВОЮ ТОПОЛОГІЄЮ ДЛЯ ПОДВІЙНОї ВІЗУАЛІЗАЦІї

Луіз Марті, Алізон Франсуа, Тетяна Крачко, Шанталь Гало, Клод Пікар, В.М.Амірханов, Ерік Бенуа Ключові слова: клік-хімія; різнолігандні комплекси; трис-карбоніл ренію(I); фрлуоресценція

В даній публікації представлені результати досліджень п'яти нових різнолігандних трис-карбонільних комплексів ренію(I) на основі піридинтриазольних похідних, так званих руtа. Такі катіонні комплекси загальної формули $\left[\operatorname{Re}(C O)_{3}(\right.$ руta-COOMe $)$ ] $(L=$ похідні піридину) поєднують карбоксилатну ффункціональну групу, яка може бути використана для подальшого біомолекулярного зв'язування з хелатованим металовмісним фррагментом на основі руtа-трис-карбонільних комплексних часточок, які можуть виступати в якості фрлуоресцентного центру. Комплекси були отримані двостадійною реакцією, заснованою на активації $\left[R e(C O){ }_{3} \mathrm{Cl}(\right.$ bipy)] трифрлатом срібла в присутності ацетонітрилу з подальщою взаємодією термічно активованого ацетонітрильного аддукту з комерційно доступними заміщеними піридинпохідними. Координаційні сполуки були отримані з різними виходами, охарактеризовані методами ЯМР-, 14- та мас-спектроскопії і досліджені їх фоотофрізичні властивості. При використанні довжини хвилі збудження, яка відповідає центру смуги переносу заряду метал-ліганд (MLCT) для кожного комплексу (смуга поглинання 300 нм), три з них виявляють яскраво-червону люмінесценцію в ацетонітрилі з центром 494 нм та квантовим виходом 0,60\%. Такі фротофрізичні особливості роблять їх потенційними фолуоресцентними біовізуалізуючими агентами. До того ж, завдяки додатковим лігандам вони можуть бути використані як основа для створення гетеробіметалічних часточок для подвійної візуалізації.

РАЗНОЛИГАНДНЫЕ КОМПЛЕКСЫ РЕНИЯ(І): ОТ ФЛУОРЕСЦЕНТНЫХ МЕТОК ДО ГЕТЕРОБИМЕТАЛЛИЧЕСКИХ ЗОНДОВ ДЛЯ ДВОЙСТВЕННОЙ ВИЗУАЛИЗАЦИИ

Луиз Марти, Ализон Франсуа, Татьяна Крачко, Шанталь Гало, Клод Пикар, В.М.Амирханов, Эрик Бенуа Ключевые слова: клик-химия; разнолигандные комплексы; трис-карбонил рения(I); фолуоресценция В данной работе представлены результаты исследований пяти новых разнолигандных трис-карбонильных комплексов рения(I) на основе пиридинтриазольных производных, так называемых рута. Такие катионные комплексы общей фрормулы $\left[\operatorname{Re}(\mathrm{CO})_{3}(\right.$ pyta-COOMe)L] $(L=$ производные пиридина) сочетают в себе карбоксилатную ффункциональную группу для дальнейшего биомолекулярного связывания с хелатированным металлсодержащим фррагментом - на основе рута-трискарбонильных комплексных частии, которые могут выступать в качестве фрлуоресцентного центра. Комплексы были получены двухстадийной реакцией, основанной на активации $\left[\operatorname{Re}(\mathrm{CO})_{3} \mathrm{Cl}(\right.$ (bipy)] трифрлатом серебра в присутствии ацетонитрила с дальнейшим взаимодействием термически активированного ацетонитрильного аддукта с коммерчески доступными замещенными пиридинпроизводными. Координационные соединения были получены с разными выходами, исследованы методами ЯМР-, ИК- и масс-спектроскопии и изучены их фотофризические свойства. При использовании длины волны возбуждения, соответствующей центру полосы переноса заряда металл-лиганд (MLCT) для каждого комплекса (полоса поглощения 300 нм), три из них проявляют ярко-зеленую люминесценцию в ацетонитриле с центром 494 нм и квантовым выходом 0,60\%. Такие фоотофризические особенности делают их потенциальными фрлуоресцентными биовизуализирующими агентами. Кроме того, благодаря дополнительным лигандам они могут быть использованы как основа для получения гетеробиметаллических частиц для двойственной визуализации. 
Optical imaging is an emerging non-invasive diagnostic modality, which offers real-time data acquisition and high spatial resolution. Although its tissue penetration is limited, its excellent sensitivity allows the detection of the fluorescent probe on the cellular level. Therefore, extensive work has been recently devoted to the development of new fluorescent cell imaging reporters. Among optical reporters, rhenium(I) tricarbonylcomplexes of the general formula $\left[\operatorname{Re}(\mathrm{CO})_{3}\left(\alpha, \alpha^{\prime}\right.\right.$-diimine)L] ( $\mathrm{L}=$ halogen or substituted pyridine derivatives), or based on diquinolinylamine scaffolds have been widely studied $[1,2]$. Their promising photophysical features such as large Stoke shifts allowing easy separation of excitation and emission, long luminescence life-times and better resistances to photobleaching compared to those of purely organic fluorescent dyes, make them promising cellular imaging probes [3]. Concerning the former kind of ternary rhenium(I) complexes, $\alpha, \alpha$ '-diimines are generally based on bipyridine or polylpyridyl derivatives.

We demonstrated previously that analogous ternary rhenium(I) complexes based on a pyridinetriazole framework, the so-called pyta, exhibited similar photophysical properties than those based on a bipy moiety $[4,5]$. The great advantage of the pyta derivative compared with the bipyridine lies in its synthesis. The pyridinetriazole scaffold was prepared via the Coppercatalyzed Alkyne-Azide Cycloaddition (CuAAC reaction) [6-8]. Due to the gentle reaction conditions of the CuAAC reaction (the reaction proceeds generally at room temperature without generating side reactions and with simple or no purification of the final product), numerous mono-functionalized 2-pyridyl1,2,3-triazole derivatives bearing a pendant arm on the triazolyl ring have been prepared in a high yield. This easy preparation contrasts with the synthesis of mono-functionalized 2,2'-bipyridine derivatives generally required multiple-step syntheses and/or fastidious purification steps and suffers from low overall yields. Finally, we reported recently the first ${ }^{99 \mathrm{~m}} \mathrm{Tc} / \mathrm{Re}$ dinuclear complex as a potential nuclear/optical imaging agent. Based on the pyta framework this dinuclear structure combines two distinct metal chelating sites: a pyta-based tricarbonylrhenium moiety as a fluorescent probe, and a ${ }^{99 \mathrm{~m}} \mathrm{Tc}\left(\mathrm{CO}_{3}\right)^{+}$core through the tridentate chelating iminodiacetic acid (IDA) clamp as a SPECT reporter [9].

In order to pursue our investigations with this kind of rhenium fluorophore based on a click chemistry strategy, we reported in this paper the synthesis of five new ternary complexes of the general formula, $\left[\operatorname{Re}(\mathrm{CO})_{3}\right.$ (pyta-COOMe)L], where $\mathrm{L}$ is a commercial meta- or para-substituted pyridine or a pyridine bearing an iminodiacetate chelating site (IDA) via a triazolyl unit. We anticipated that using such substituted pyridines as an ancillary ligand could lead to (i) novel ternary $\operatorname{Re}(\mathrm{I})$ complexes as potential optical reporters, (ii) fluorescent scaffolds for the further preparation of novel heterobimetallic species. Then, in this paper, the synthesis, characterization and photophysical features of these rhenium complexes were described. We also demonstrated that the nature of the ancillary ligand, $\mathrm{L}$, had a direct impact on the electronic properties of the Re-complexes.

\section{Results and Discussion}

The synthetic strategies are illustrated in Scheme. The ternary rhenium complexes were prepared using a classical two-steps pathway involved the activation of $\left[\mathrm{Re}(\mathrm{CO})_{3} \mathrm{Cl}\right.$ (bipy)] with triflate silver salts in the presence of acetonitrile [4] followed by the thermally activated substitution of the reactive acetonitrile adduct 2 by commercially available meta- or para-substituted pyridine moieties or a di-tert-butyl $N$-[1-(4-pyridyl)-1H-1,2,3-triazol-4-yl)methyl]iminodiacetate intermediate 7 [10]. Although direct substitution of a chlorine ion of the chloro-rhenium complex by pyridine derivatives in the presence of silver is possible, in our hands, we never succeeded to isolate the corresponding ternary rhenium complexes in a correct yield. The different complexes were obtained from modest to good yields (from 38\% to $87 \%$ ) depending on the nature of the pyridine species.

If the best yield is obtained with the meta-aminopyridine, it seems that para-substituted pyridine entities are more appropriate to prepare the corresponding ternary complexes in a correct yield, as demonstrated by a higher yield obtained for 3 compared with $\mathbf{4}$, and the fact that we never succeeded to prepare the structural analogue of $\mathbf{8}$ using di-tert-butyl $N$-[1-(3-pyridyl)-1H-1,2,3-triazol-4-yl)methyl]iminodiacetate as an ancillary ligand. Additionally, although not very stable, we succeeded to isolate compound $\mathbf{5}$ (bromomethyl arm) in a modest yield. This interesting result contrasted with the previous conclusions of Coogan et al. concerning the formation of a similar 3-chloromethylpyridyl bipyridine tricarbonyl-rhenium complex [11]. Indeed, their reaction conditions, close to ours, did not give the desired ternary complex, but the precursor material $\left[\operatorname{Re}(\mathrm{CO})_{3}(\mathrm{bipy}) \mathrm{Cl}\right]$ instead of this. Our result suggests that ternary $\operatorname{Re}(\mathrm{I})$ complexes with a (halogenomethyl)pyridine as an ancillary ligand could be synthesized directly, nevertheless, its poor stability renders its isolation difficult. Finally, from the synthetic point of view, the use of 7 instead of 4-pyrIDA-tBu [9] as an ancillary ligand for introduction of the second chelating entity on the rhenium core is interesting. The ditopic ligand $\mathbf{7}$ is obtained readily (one night) by a CuAAC reaction in $77 \%$ yield, while the 4-pyrIDA-tBu moiety was prepared in $59 \%$ yield in 60 hours of the reaction. Nevertheless, it is noteworthy that two major products were obtained from the reaction of $\mathbf{2}$ with 


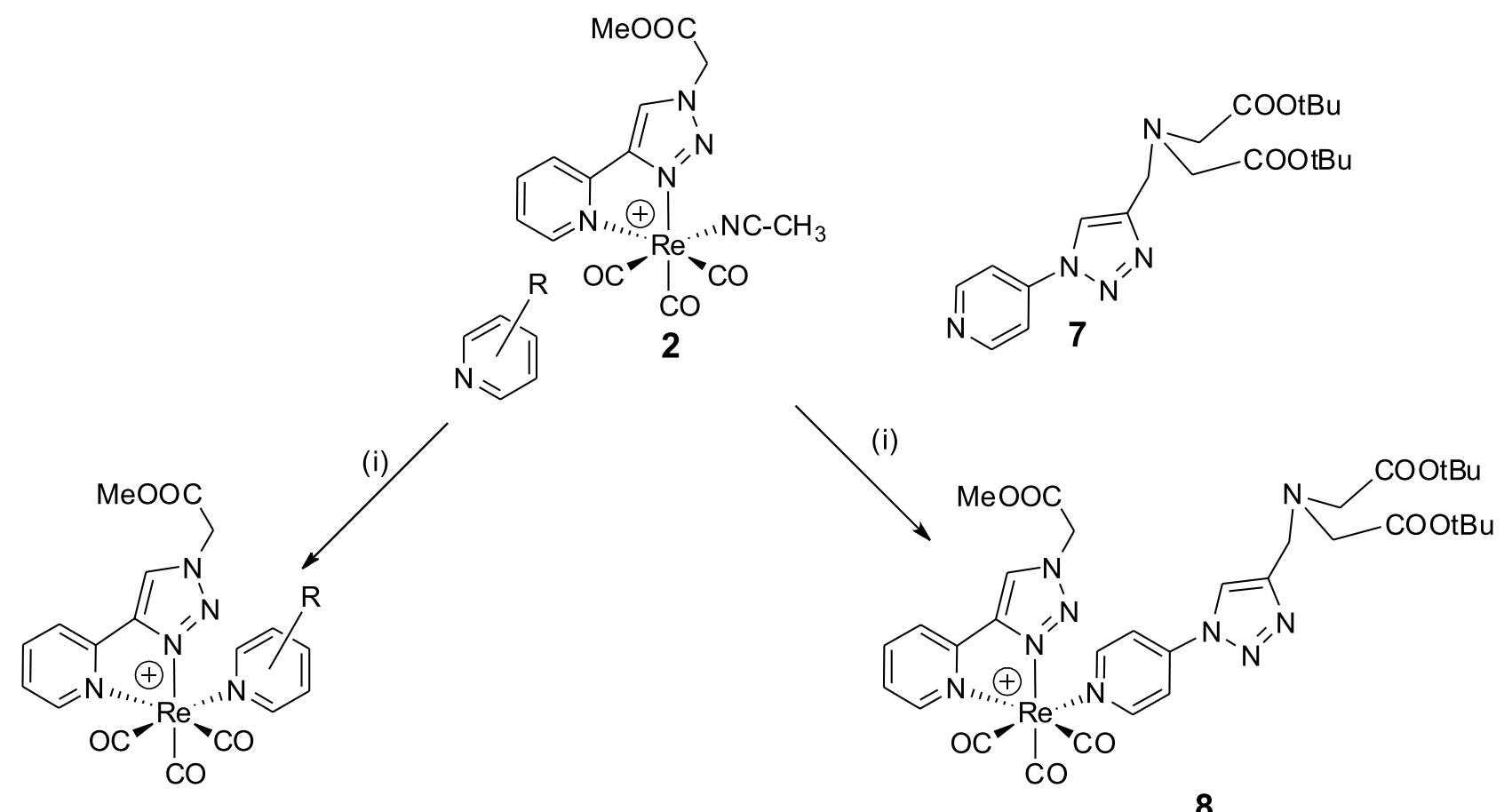

Scheme. Thermally activated substitutions of 2 by substituted pyridine derivatives (the reaction conditions: THF, 5h, reflux).

intermediate 7. After HPLC purification, compound 8 was obtained in $38 \%$ yield. The second product was a structural isomer of $\mathbf{8}$ exhibiting the same MS spectrum assignment. We could suggest that this compound resulted from the coupling of $\mathbf{7}$ to $\mathbf{2}$ via one nitrogen atom of the triazolyl unit of $\mathbf{7}$.

All the ternary $\operatorname{Re}(\mathrm{I})$ complexes have been fully characterized by ${ }^{1} \mathrm{H}$ and ${ }^{13} \mathrm{C}$ NMR, and ESI-mass spectrometry. As expected, they were cationic and obtained as triflate salts, as confirmed by both, the quadruplet corresponding to the $\mathrm{CF}_{3}$ part of the triflate ion observed in the ${ }^{13} \mathrm{C}$ spectra and the presence of the triflate ion in the negative-ion ESI mass spectra. The presence of the $\mathrm{fac}^{-} \mathrm{ReCO}_{3}{ }^{+}$core was confirmed by ${ }^{13} \mathrm{C}$ NMR, with three peaks at 191-199 ppm region. The electronic spectra of the complexes showed the typical features associated with this kind of ternary complexes, i.e. ligand-centered bands at higher energy corresponding to $\pi \rightarrow \pi^{*}$ transitions and metal-toligand charge-transfer (MLCT) bands at lower energy corresponding to $\mathrm{d} \pi(\mathrm{Re}) \rightarrow \pi^{*}$ (pyta core).

The photophysical study has been performed with four complexes, compound $\mathbf{5}$ being not stable enough.

Table 1

The compounds synthesized

\begin{tabular}{|c|c|c|}
\hline Compound & $\mathrm{R}$ & Yield, $\%$ \\
\hline 3 & $p-\mathrm{CH}_{2} \mathrm{OH}$ & 67 \\
\hline 4 & $m-\mathrm{CH}_{2} \mathrm{OH}$ & 48 \\
\hline 5 & $p-\mathrm{CH}_{2} \mathrm{Br}$ & 42 \\
\hline 6 & $m-\mathrm{NH}_{2}$ & 87 \\
\hline 8 & 7 & 38 \\
\hline
\end{tabular}

Determination of the luminescent features $\left(\lambda_{\text {exc }}, \lambda_{\text {em }}, F\right)$ of each complex has been performed at room temperature, in acetonitrile solution using $\mathrm{Ru}$ (bipy) ${ }_{3} \mathrm{Cl}_{2}$ as a reference for determining the quantum yield [12]. After irradiation of the MLCT transition of each complex (absorption band at $c a .300 \mathrm{~nm}$ ), complexes 3, 4 and 8 exhibit a large emission band at 494, 492 and $496 \mathrm{~nm}$, respectively, while 6 is not luminescent (Table 2). The room temperature quantum yields of the three luminescent complexes have been calculated (Table 2), the values being in agreement with the values reported for the similar cationic rhenium complexes based on the bipyridine framework and the values measured for other Re(I)-pyta complexes [4, 5]. Surprisingly, it is noteworthy that extension of the $\pi$-backbone of the pyridine core of the ancillary ligand in 8, through the direct connection of a triazolyl unit on the pyridine ring, does not have a significant impact on the luminescent properties of the corresponding rhenium complex.

\section{Experimental Part}

All chemicals and analytical grade solvents purchased were used without further purification

Table 2

Electronic emission spectral data and quantum yields $(\Phi)$ in acetonitrile, at $298 \mathrm{~K}$

\begin{tabular}{|c|c|c|c|}
\hline Compound & $\lambda_{\text {exc }}(\mathrm{nm})$ & $\lambda_{\text {em }}(\mathrm{nm})$ & $\Phi(\%)^{[12]}$ \\
\hline 3 & 294 & 494 & 0.64 \\
\hline 4 & 295 & 492 & 0.61 \\
\hline 6 & 296 & - & - \\
\hline 8 & 292 & 496 & 0.71 \\
\hline
\end{tabular}


$\left[\mathrm{Re}(\mathrm{CO})_{3}(\right.$ pyta-COOMe)Cl], $\mathbf{1}$, and $\mathbf{7}$ were prepared according to literature protocols $[4,10]$. The ${ }^{1} \mathrm{H}$, and ${ }^{13} \mathrm{C}$ NMR spectra were recorded at 300 (75.5) MHz or at 500 (125) MHz (Bruker spectrometers). Chemical shifts are reported in parts per million relative to a residual solvent peak (acetone- $\mathrm{d}_{6}$ ). Coupling constants (J) are given in Hertz (Hz) and peak multiplicity is reported as singlet $(\mathrm{s})$, doublet $(\mathrm{d})$, triplet $(\mathrm{t})$, multiplet (m). ESI Mass spectra were obtained on a Perkin Elmer Sciex API 365 or a Applied Biosystem $\mathrm{Q}$ trap mass spectrometers. Fluorescence spectra were obtained with a Cary Eclipse spectrofluorimeter equipped with a Xenon flash lamp source and a Hamamatsu R928 photomultiplier tube.

$\left[\operatorname{Re}\left(\mathrm{CO}_{3}{ }_{3}(\mathrm{pyta}-\mathrm{COOMe})(\mathrm{ACN})\right][\mathrm{OTf}](2)\right.$

To the solution of $1(202 \mathrm{mg}, 0.386 \mathrm{mmol})$ in distilled acetonitrile $(40 \mathrm{~mL})$, the solution of silver triflate $(119 \mathrm{mg}, 0.463 \mathrm{mmol})$ in distilled THF ( $4 \mathrm{~mL})$ was added under argon. The mixture was refluxed in the dark overnight. After cooling, the solution was filtered off on sintered glass, then twice on a $0.45 \mu \mathrm{m}$ PTFE-Millipore. The solvent was evaporated, giving a white powder which was used with no further purification (250 mg). Yield: 95\%. MS: $\mathrm{m} / \mathrm{z}=528$ [M-OTf] ${ }^{+}$.

General procedure for the synthesis of ternary rhenium(I) complexes 3, 4, 5, 6 and 8: To $0.36 \mathrm{mmol}$ ( $250 \mathrm{mg}$ ) of 2 in $50 \mathrm{~mL}$ of distilled THF, $1.8 \mathrm{mmol}$ (5 eq.) of the given ancillary ligand were added, under the nitrogen atmosphere. The mixture was refluxed for $5 \mathrm{~h}$ and then stirred at r.t. for 2 days. The desired complex was precipitated by several additions of pentane $(50 \mathrm{~mL})$.

Complex 3:

$200 \mathrm{mg}$ of 4-(hydroxymethyl)pyridine led to $180 \mathrm{mg}$ of 3. Yield: $67 \% .{ }^{1} \mathrm{H} \mathrm{NMR} \mathrm{(500} \mathrm{MHz):} \delta, \mathrm{ppm}=3.86 \mathrm{~s}$ $\left(3 \mathrm{H}, \mathrm{CH}_{3}\right), 4.67 \mathrm{~s}\left(2 \mathrm{H}, \mathrm{CH}_{2} \mathrm{OH}\right), 5.82 \mathrm{~s}\left(2 \mathrm{H}, \mathrm{CH}_{2}\right), 7.45$ $\mathrm{m}\left(2 \mathrm{H}, \mathrm{CH}_{\mathrm{pyr}}\right), 7.89 \mathrm{ddd}(1 \mathrm{H}, J=8.1 \mathrm{~Hz}, J=5.7 \mathrm{~Hz}$, $\left.J=2.4 \mathrm{~Hz}, \mathrm{CH}_{\text {pyta }}\right), 8.38 \mathrm{~m}\left(2 \mathrm{H}, \mathrm{CH}_{\text {pyta }}\right), 8.41 \mathrm{~m}(2 \mathrm{H}$, $\left.\mathrm{CH}_{\text {pyr }}\right), 9.26 \mathrm{~s}\left(1 \mathrm{H}, \mathrm{CH}_{\text {pyta }}\right), 9.45 \mathrm{ddd}(1 \mathrm{H}, J=5.7 \mathrm{~Hz}$, $\left.J=1.5 \mathrm{~Hz}, J=0.9 \mathrm{~Hz}, \mathrm{CH}_{\text {pyta }}\right) ;{ }^{13} \mathrm{CNMR}(125 \mathrm{MHz}): \delta$, $\mathrm{ppm}=54.4\left(\mathrm{CH}_{2}\right), 54.6\left(\mathrm{CH}_{3}\right), 63.3\left(\mathrm{CH}_{2} \mathrm{O}\right), 120.0(\mathrm{q}$, $\left.\mathrm{CF}_{3}, J=320 \mathrm{~Hz}\right), 125.5\left(2 \mathrm{CH}_{\mathrm{pyr}}+\mathrm{CH}_{\mathrm{pyta}}\right), 129.7,130.0$, 143.7, $156.0\left(\mathrm{CH}_{\text {pyta }}\right), 151.0,151.3\left(\mathrm{C}_{\text {pyta }}\right), 153.5\left(2 \mathrm{CH}_{\text {pyr }}\right)$, $158.7\left(\mathrm{C}_{\text {pyr }}\right), 168.2$ (COOMe), 191.4-195.7 (3C $\left.\equiv 0\right) ; M S$ : $\mathrm{m} / \mathrm{z}=598\left[\mathrm{M}^{+}\right]$, HRMS: $\mathrm{m} / \mathrm{z}$ calcd (found) 596.0731 (596.0709) $[\mathrm{M}]^{+}$.

\section{Complex 4:}

$200 \mathrm{mg}$ of 3-(hydroxymethyl)pyridine led to $130 \mathrm{mg}$ of 4. Yield: $48 \% .{ }^{1} \mathrm{H} \mathrm{NMR}(500 \mathrm{MHz}): \delta, \mathrm{ppm}=3.87 \mathrm{~s}$ $\left(3 \mathrm{H}, \mathrm{CH}_{3}\right), 4.60 \mathrm{~s}\left(2 \mathrm{H}, \mathrm{CH}_{2} \mathrm{OH}\right), 5.82 \mathrm{~s}\left(2 \mathrm{H}, \mathrm{CH}_{2}\right), 7.45$ $\operatorname{ddd}\left(1 \mathrm{H}, J=7.8 \mathrm{~Hz}, J=5.4 \mathrm{~Hz}, J=0.6 \mathrm{~Hz}, \mathrm{CH}_{\text {pyta }}\right), 7.89$ $\mathrm{m}\left(1 \mathrm{H}, \mathrm{CH}_{\text {pyta }}\right), 7.97 \mathrm{~m}\left(2 \mathrm{H}, \mathrm{CH}_{\text {pyr }}\right), 8.38 \mathrm{~m}\left(1 \mathrm{H}, \mathrm{CH}_{\text {pyta }}\right)$, $8.45 \mathrm{~m}\left(2 \mathrm{H}, \mathrm{CH}_{\mathrm{pyr}}\right), 9.25 \mathrm{~s}\left(1 \mathrm{H}, \mathrm{CH}_{\text {pyta }}\right), 9.46$ (ddd, $1 \mathrm{H}, J=$ $\left.5.7 \mathrm{~Hz}, J=1.5 \mathrm{~Hz}, J=0.9 \mathrm{~Hz}, \mathrm{CH}_{\mathrm{pyta}}\right) ;{ }^{13} \mathrm{CNMR}(125 \mathrm{MHz})$ : $\delta, \mathrm{ppm}=54.4\left(\mathrm{CH}_{2}\right), 54.6\left(\mathrm{CH}_{3}\right), 62.0\left(\mathrm{CH}_{2} \mathrm{O}\right), 119.8$ $\left(\mathrm{q}, \mathrm{CF}_{3}, \mathrm{~J}=320 \mathrm{~Hz}\right), 128.2,129.7,130.0,143.5,143.7$ $\left(\mathrm{CH}_{\text {pyta }}\right), 138.3,139.9,152.0,156.0\left(\mathrm{CH}_{\mathrm{pyr}}\right), 150.9,151.2$
$\left(\mathrm{C}_{\text {pyta }}\right), 152.4\left(\mathrm{C}_{\text {pyr }}\right), 168.3$ (COOMe), 193.2-197.4 (3C $\left.\equiv 0\right)$; $M S: \mathrm{m} / \mathrm{z}=598$ [M+1 $]$ HRMS: $\mathrm{m} / \mathrm{z}$ calcd (found) 596.0731 (596.0722) $[\mathrm{M}]^{+}$.

\section{Complex 5:}

$460 \mathrm{mg}$ of 4-(bromomethyl)pyridine led to $143 \mathrm{mg}$ of 5. Yield: $42 \% .{ }^{1} \mathrm{H} \mathrm{NMR}(300 \mathrm{MHz}): \delta, \mathrm{ppm}=3.84 \mathrm{~s}$ $\left(3 \mathrm{H}, \mathrm{CH}_{3}\right), 4.98 \mathrm{~s}\left(2 \mathrm{H}, \mathrm{CH}_{2}\right), 5.71 \mathrm{~s}\left(2 \mathrm{H}, \mathrm{CH}_{2}\right), 7.68 \mathrm{~m}$

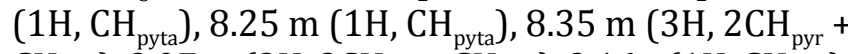
$\left.\mathrm{CH}_{\text {pyta }}\right), 9.07 \mathrm{~m}\left(3 \mathrm{H}, 2 \mathrm{CH}_{\text {pyr }}+\mathrm{CH}_{\text {pyta }}\right), 9.16 \mathrm{~s}\left(1 \mathrm{H}, \mathrm{CH}_{\text {pyta }}\right)$; ${ }^{13} \mathrm{C} \mathrm{NMR}(75 \mathrm{MHz}): \delta$, ppm = $30.7\left(\mathrm{CH}_{2} \mathrm{Br}\right), 53.9\left(\mathrm{CH}_{2}\right)$, $54.5\left(\mathrm{CH}_{3}\right), 120.5\left(\mathrm{q}, \mathrm{CF}_{3}, J=320 \mathrm{~Hz}\right), 124.6,128.1,128.5$, 142.1, $155.1\left(\mathrm{CH}_{\text {pyta }}\right), 129.6,144.0\left(2 \mathrm{x} 2 \mathrm{CH}_{\mathrm{pyr}}\right), 150.7$, $151.1\left(\mathrm{C}_{\text {pyta }}\right), 161.0\left(\mathrm{C}_{\text {pyr }}\right), 168.3$ (COOMe), 197.8-199.3 $(3 \mathrm{C} \equiv 0) ; M S: \mathrm{m} / \mathrm{z}=742[\mathrm{M}+\mathrm{HBr}]^{+}$.

Complex 6:

$170 \mathrm{mg}$ of 3-aminopyridine led to $230 \mathrm{mg}$ of 6 . Yield: $87 \% .{ }^{1} \mathrm{H} N M R(500 \mathrm{MHz}): \delta, \mathrm{ppm}=3.79 \mathrm{~s}(3 \mathrm{H}$, $\left.\mathrm{CH}_{3}\right), 5.852 \mathrm{~d}\left(2 \mathrm{H}, J=10 \mathrm{~Hz}, \mathrm{CH}_{2}\right), 7.03 \mathrm{~m}\left(2 \mathrm{H}, \mathrm{H}_{\mathrm{pyr}}\right)$, $7.37 \mathrm{~m}\left(1 \mathrm{H}, \mathrm{H}_{\text {pyr }}\right), 7.69 \mathrm{~m}\left(1 \mathrm{H}, \mathrm{H}_{\text {pyr }}\right), 7.83 \mathrm{~m}\left(1 \mathrm{H}, \mathrm{H}_{\text {pyta }}\right)$, $8.39 \mathrm{~m}\left(2 \mathrm{H}, \mathrm{H}_{\text {pyta }}\right), 9.24 \mathrm{~m}\left(1 \mathrm{H}, \mathrm{H}_{\text {pyta }}\right), 9.25 \mathrm{~s}\left(1 \mathrm{H}, \mathrm{H}_{\text {pyta }}\right)$; ${ }^{13} \mathrm{C} \mathrm{NMR}(125 \mathrm{MHz}): \delta, \mathrm{ppm}=53.0\left(\mathrm{CH}_{2}\right), 53.6\left(\mathrm{CH}_{3}\right)$, $119.9\left(\mathrm{q}, \mathrm{CF}_{3}, J=320 \mathrm{~Hz}\right), 122.4,127.1,137.9,138.9$ $\left(\mathrm{CH}_{\text {pyr }}\right), 123.3,128.3,128.7,141.3,154.5\left(\mathrm{CH}_{\text {pyta }}\right), 147.8$ $\left(\mathrm{C}_{\text {pyr }}\right), 148.6,149.1\left(\mathrm{C}_{\text {pyta }}\right), 167.1$ (COOMe), 192.3-196.3 $(3 \mathrm{C} \equiv 0) ; M S: \mathrm{m} / \mathrm{z}=582[\mathrm{M}]^{+}$.

\section{Complex 8:}

$650 \mathrm{mg}$ of 7 led to $128 \mathrm{mg}$ of 8 after HPLC purification (XBridge C18 column, $150 \times 19 \mathrm{~mm}$, flow: $20 \mathrm{~mL} / \mathrm{min}$., solvent: $\mathrm{H}_{2} \mathrm{O}-0.1 \% \mathrm{TFA} / \mathrm{CH}_{3} \mathrm{CN}-0.1 \% \mathrm{TFA}$, gradient: 0 2 min., $90 / 10$ to $45 / 55$; 2-11 min., 35/65. $\lambda=240 \mathrm{~nm}$. Yield: $38 \% .{ }^{1} \mathrm{H} N \mathrm{NR}(500 \mathrm{MHz}): \delta, \mathrm{ppm}=1.44 \mathrm{~s}(18 \mathrm{H}$, $\left.\mathrm{CH}_{3}\right), 3.75 \mathrm{~s}\left(4 \mathrm{H}, \mathrm{CH}_{2}\right), 3.88 \mathrm{~s}\left(3 \mathrm{H}, \mathrm{CH}_{3}\right), 4.40 \mathrm{~s}(2 \mathrm{H}$, $\left.\mathrm{CH}_{2}\right), 5.62 \mathrm{~s}\left(2 \mathrm{H}, \mathrm{CH}_{2}\right), 7.90 \mathrm{~m}\left(1 \mathrm{H}, \mathrm{CH}_{\text {pyta }}\right), 8.10 \mathrm{~m}(2 \mathrm{H}$, $\left.\mathrm{CH}_{\text {pyr }}\right), 8.40 \mathrm{~m}\left(2 \mathrm{H}, \mathrm{CH}_{\text {pyta }}\right), 8.70 \mathrm{~m}\left(2 \mathrm{H}, \mathrm{CH}_{\text {pyr }}\right), 8.85 \mathrm{~s}$ $(1 \mathrm{H}, \mathrm{CH}), 9.35 \mathrm{~s}\left(1 \mathrm{H}, \mathrm{CH}_{\mathrm{pyta}}\right), 9.50 \mathrm{~m}\left(1 \mathrm{H}, \mathrm{CH}_{\text {pyta }}\right) ;{ }^{13} \mathrm{C}$ $\operatorname{NMR}(125 \mathrm{MHz}): \delta, \mathrm{ppm}=27.3\left(\mathrm{CH}_{3 \mathrm{tBu}}\right), 48.6\left(\mathrm{CH}_{2}\right), 52.6$ $\left(\mathrm{CH}_{2}\right), 52.8\left(\mathrm{CH}_{30 \mathrm{Me}}\right), 54.4\left(2 \mathrm{CH}_{2}\right), 81.5\left(\mathrm{C}_{\mathrm{tBu}}\right), 116.0$ $\left(\mathrm{q}, \mathrm{CF}_{3}, J=320 \mathrm{~Hz}\right), 116.2\left(2 \mathrm{CH}_{\mathrm{pyr}}\right), 123.2(\mathrm{CH}), 123.7$ $\left(\mathrm{CH}_{\text {pyta }}\right), 127.9\left(2 \mathrm{CH}_{\text {pyta }}\right), 141.9\left(\mathrm{CH}_{\text {pyta }}\right), 144.6\left(\mathrm{C}_{\text {pyr }}\right)$, $144.9(\mathrm{C}), 149.2\left(\mathrm{C}_{\text {pyta }}\right), 149.6\left(\mathrm{C}_{\text {pyta }}\right), 154.3\left(2 \mathrm{CH}_{\mathrm{pyr}}+\right.$ $\mathrm{CH}_{\text {pyta }}$ ), 166.4 (COOMe), 168.3 (COOtBu), 194.0-198.3 $(3 \mathrm{C} \equiv 0) ; M S: \mathrm{m} / \mathrm{z}=893\left[\mathrm{M}^{+}\right] ; H R M S: \mathrm{m} / \mathrm{z}$ calcd (found) $890.2387(890.2400)[\mathrm{M}]^{+}$; HPLC: $\mathrm{t}_{\mathrm{r}}=4.41 \mathrm{~min}$.

\section{Conclusions}

In summary, five ternary tricarbonylrhenium(I) complexes based on a pyridinetriazole moiety obtained by click chemistry have been prepared from correct to good yields. We showed that the nature of the ancillary ligand could affect the electronic properties of the ternary Re-complexes. If the hydroxymethylpyridine moieties or ditopic ligand $\mathbf{7}$ unaffected the photo-physical properties of their corresponding Re-complexes, the use of aminopyridine as an ancillary ligand quenched the luminescence. The three fluorescent cationic complexes should not be considered as simple optical reporters but also as interest- 
ing scaffolds for the preparation of optical/nuclear dual-imaging species, by coupling a second chelating unit on the hydroxyl arm of compounds $\mathbf{3}$ or $\mathbf{4}$ fol- lowed by radiolabeling of this chelating site or by labeling the IDA chelating site of 8 with the ${ }^{99 \mathrm{~m}} \mathrm{Tc}(\mathrm{CO})_{3}{ }^{+}$ core. This work is currently under investigation.

\section{References}

1. Fernandez-Moreira V., Thorp-Greenwood F.L., Coogan M.P.//Chem. Commun. - 2010. - Vol. 46. - P. 186-202.

2. Coleman A., Brennan C., Vos J.G. et al. // Coord. Chem. Rev. - 2008. - Vol. 252. - P. 2585-2595.

3. Balasingham R.G., Coogan M.P., Thorp-Greenwood F.L. // Dalton Trans. -2011. -Vol. 40. - P. 11663-11674.

4. Boulay A., Seridi A., Zedde C. et al. // Eur. J. Inorg. Chem. - 2010. - P. 5058-5062.

5. Wolff M., Munoz L., François A. et al. // Dalton Trans. - 2013. - Vol. 42. - P. 7019-7031.

6. Kolb H.C., Finn M.G., Sharpless K.B. // Angew. Chem. Int. Ed. - 2001. - Vol. 40. - P. 2004-2021.

7. Rostovtsev V.V., Green L.G., Fokin V.V. et al. // Angew. Chem. Int. Ed. - 2002. - Vol. 41. - P. 2596-2599.

8. Meldal M., Tornøe C.W. // Chem. Rev. - 2008. - Vol. 108. - P. 2952-3015.

9. François A., Auzanneau C., Le Morvan V. et al. // Dalton Trans. - 2013. - accepted.

10. François A., Marty L., Picard C. et al. // Acta Cryst. E. - 2012. - Vol. E68. - P. o3162.

11. Amoroso A.J., Arthur R.J., Coogan M.P. et al. // New J. Chem. - 2008. - Vol. 32. - P. 1097-1102.

12. Ishida H., Tobita S., Hasegawa Y. et al. // Coord. Chem. Rev. - 2010. - Vol. 254. - P. 2449-2458.

Надійшла до редакції 25.10.2013 p. 